\title{
GAMBARAN KOMITMEN ORGANISASI PERUSAHAAN BIDANG KONTRUKSI PT. XYZ DI JAKARTA BARAT
}

\author{
Yohanes Ari Setiawan ${ }^{1}$ dan Zamralita ${ }^{2}$ \\ ${ }^{1}$ Fakultas Psikologi, Universitas Tarumanagara \\ Email: y.ari.setiawan@gmail.com \\ ${ }^{2}$ Fakultas Psikologi, Universitas Tarumanagara \\ Email: zamralita04@yahoo.com
}

\begin{abstract}
ABSTRAK
Komitmen organisasi memiliki peranan penting dalam menigkatkan produktivitas kinerja karyawan. Tingginya turn over yang berada pada PT. XYZ selama tiga tahun terakhir ini seringkali dikaitkan dengan komitmen organisasi karyawan yang rendah sehingga penelitian ini untuk memberikan gambaran komitmen organisasi pada PT. XYZ. Metode yang digunakan dalam penelitian ini adalah kuantitatif deskriptif dengan total populasi 72 karyawan yang disebar melalui kuetioner komitmen organisasi dan yang ikut berpartisipasi dan mengembalikan jawaban 40 orang. Hasil penelitian menunjukkan komitmen organisasi pada PT. XYZ secara keseluruhan tergolong sedang dengan mean 2,616. Dilihat dari setiap dimensi komitmen organisasi karyawan PT. XYZ menunjukan dimensi affective comitment tergolong sedang dengan mean 2,941, dimensi normative commitment tergolong sedang dengan mean 2,403, dan dimensi continuance commitment tergolong sedang dengan mean 2,504.
\end{abstract}

Kata kunci: Komitmen organisasi, affective commitment, continuance commitment, normative commitment

\section{PENDAHULUAN}

\section{Latar Belakang}

PT. XYZ adalah perusahaan yang bergerak di bidang Design interior dan arsitektur yang sudah berdiri sejak 1994. PT. XYZ ingin terus mempertahankan eksistensi dalam dunia bisnis diharapkan dapat meningkatkan kualitas dalam pelayanan produk dan pemasangan dalam bidang arsitek dan design interior. Pelayanan yang berkualitas diperoleh dari SDM yang berkualitas. SDM yang ada sampai saat ini mencapai 72 orang dengan perkembangan di tiap tahunnya. Peningkatan karyawan bertujuan untuk meningkatkan efisiensi dan efektifitas di lingkungan kerja. Karyawan yang merupakan aset adalah yang menggerakan bisnis yang dijalankan oleh perusahaan. Hanya saja seiring berjalannya waktu dinamika dari karyawan tidak bisa dihindari selain ada penambahan karyawan juga ada karyawan yang mengundurkan diri. Berikut adalah data turnover yang terjadi pada PT. XYZ selama tiga tahun terakhir. 
Tabel 1. Data turnover PT. XYZ

\begin{tabular}{cccc}
\hline & 2014 & 2015 & 2016 \\
\hline Finance & 1 & - & - \\
Accounting & 1 & 1 & 1 \\
Purchasing & 1 & - & 2 \\
Project & 2 & 1 & 5 \\
Engineering & - & - & - \\
HRD & - & - & 1 \\
GA & - & 3 & 1 \\
\hline Sales \& Marketing & 3 & 4 & 11 \\
\hline Total & 8 & 9 & \\
\hline
\end{tabular}

Berdasarkan gambaran turn over seperti yang disajikan data diatas mengalami peningkatan di tiap tahunnya. Presentase turnover yang dialami termasuk kategori tinggi. Berikut perhitungan peningkatan turnover di tiap tahun selama tiga tahun terkahir

Tabel 2. Presentase turnover karyawan PT. XYZ

\begin{tabular}{cccc}
\hline & 2014 & 2015 & 2016 \\
\hline Jan & 49 & 54 & 53 \\
Des & 54 & 53 & 57 \\
\hline$\%$ & $15.68 \%$ & $16.82 \%$ & $20 \%$ \\
\hline
\end{tabular}

Karyawan yang benar-benar ingin mempertimbangkan berhenti dari pekerjaan mereka, karyawan akan berpikir serta sudah memiliki niat untuk keluar dari organisasi. Tiga tahapan karyawan untuk meninggalkan organisasi dimulai dengan berpikir untuk meninggalkan organisasi, niat untuk mencari pekerjaan baru dan akhirnya diarahkan ke dalam tensi untuk pergi (Fakenburg \& Schyns, 2007) Kecenderungan seperti itu jika terus berlangsung potensial mengakibatkan penurunan kinerja organisasi secara keseluruhan.

Turnover memberikan dampak negatif bagi perusahaan. Azeem dikutip dalam Sawitri, Musadieq, dan Afrianty (2016) menyatakan bahwa penurunan tingkat turnover berimplikasi pada penurunan biaya perusahaan salah satu contohnya biaya perekrutan dan pelatihan untuk karyawan baru. Hal Tersebut berarti ketika turnover meningkat maka perusahaan akan terus mengeluarkan biaya 
lebih untuk merekrut karyawan. Perusahaan harus mengetahui dan meprediksi tingkat turnover dengan mengidentifikasi lebih awal dengan turnover intention. Gregory et al (dalam Albattat et al.)2013 membuktikan turnover intention adalah peramal yang akurat pada tingkat turnover yang sebenarnya. Salah satu prediktor yang digunakan untuk mengukur turnover intention adalah melalui komitmen organisasonal. Hal tersebut sesua dengan hasil penelitian yang ditemukan oleh Meyer et al dikutip dalam Sersic (1990) yang menyebutkan adanya kontribusi yang signifikan dari komitmen organisasional dalam memprediksi turnover intention. Labatmedienne et al (2007) menyatakan bahwa dengan memahami komitmen organisasi mengetahui hubungan antara komitmen organisasional dengan turnover intention. Basuki \& Tunggal (2016) juga menyampaikan adanya pengaruh komitmen organisasi terhadap turnover intention. Maka dari itu data turnover PT. XYZ sebagai data awal untuk mengukur komitmen organisasi dari karyawan PT. XYZ.

Komitmen karyawan merupakan faktor penting untuk meningkatkan kinerja organisasi. Komitmen organisasi adalah komitmen karyawan untuk membantu tercapainya tujuan organisasi, dan melibatkan tingkat identifikasi, keterlibatan, dan loyalitas karyawan (Allen \& Meyer, 1990). Allen \& Meyer (1990)mengungkapan ada tiga dimensi pada organisasi komitmen adalah affective yaitu individu mengetahui tujuan dan nilai dari organisasi , continuance yaitu ketika individu menyadari hubungan dengan organisasi, dan normative comitment yaitu muncul karena standa perilaku dan social norma perusahaan. .

Manfaat komitmen organisasi yang besar dan akibat yang ditimbulkan jika ada penurunan merupakan alasan penting utnuk membangun komitmen organisasi pada karyawan di PT. XYZ. Komitmen organisasi dapat berpengaruh terhadap produktivitas karyawan. Hal ini didukung oleh penelitian dari Hernawaty (2017) menyebutkan ada pengaruh positif komitmen organisasi dan produktivitas karyawan pada PT. Home center di Medan. Abdulah (2017) menyatakan pengaruh positif komitmen organisasional terhadap produktivitas kerja karyawan Bank cabang Majalengka. Penelitian ini menunjukan pentingnya komitmen organisasi terhadap kemajuan perushaan ditinjau dari produktivitas kerja karyawan.

Pentingnya komitment organisasi juga terkait dengan kinerja dari karyawan. Wahyudi dan Sudibya (2016) menyatakan ada pengaruh positif komitmen organisasi dengan kinerja karyawan hotel di Kuta Bali. Hal ini juga didukung dengan penelitian dari Tamonsang dan dihardjo (2017) menyatakan ada pengaruh komitmen organisasi terhadap kinerja karyawan di dinakertrans jawa timur. Hal ini mengingat komitmen organisasi karyawan merupakan kekuatan penting dalam tubuh organisasi. Hilangnya komitmen karyawan berarti organisasi kehilangan dukungan dan loyalitas dari karyawan.

\section{METODE PENELITIAN}

Penelitian ini merupakan penelitian deskriptif kuantitatif. Penelitian deskriptif bertujuan untuk menyajikan gambaran lengkap mengenai setting sosial dan klarifikasi mengenai suatu fenomena atau kenyataan sosial dengan mendeskripsikan sejumlah variabel yang berkenaan dengan masalah dan unit yang diteliti

\section{Latar dan partisipan penelitian}

Penelitian ini dilakukan di PT. XYZ yang berada di Jakarta Barat. Perusahaan yang bergerak di bidang design interior dan arsitektur. Pertimbangan memilih perusahaan tersebut dikarenakan tingginya tingkat turn over selama tiga tahun terakhir pada perusahaan ini sehingga untuk melihat komitmen organisasi karyawan pada perusahaan tersebut. Partisipan merupakan populasi 
dari karyawan tersebut sejumlah 72 orang dan yang mengisi dan berpartisipasi sejumlah 40 orang. Peneliti menyebar keseluruh karyawan hanya saja pada batas waktu yang ditentukan hanya 40 partisipan yang mengisi dan mengembalikan jawaban kuetioner/ Adapun gambaran partisipan penilitian sebagai beirkut:

Tabel 3. Gambaran partisipan berdasarkan jenis kelamin

\begin{tabular}{ccc}
\hline Jenis kelamin & Frekuensi & Presentase \\
\hline Laki-laki & 13 & 32.5 \\
Perempuan & 27 & 67.5 \\
\hline Total & 40 & 100 \\
\hline
\end{tabular}

Tabel 4. Gambaran partisipasi berdasarkan tingkat pendidikan

\begin{tabular}{ccc}
\hline Pendidikan & Frekuensi & resentase \\
\hline SMA/ SMK & 7 & 17.5 \\
S1 & 33 & 82.5 \\
\hline Total & 40 & 100 \\
\hline
\end{tabular}

\section{Pengukuran}

Variabel komitmen organisasi diukur menggunakan alat ukur yang disusun berdasarkan Allen \& Meyer (1990), terdiri dari tiga dimensi: (a) continuance comitment, (b) affective comitment, dan (c) normative commitment. Alat ukur komitmen organisasi teridri dari 36 butir pernyataan mencakup butir positif maupun butir negatif, dengan pilihan respon yang berasal dari 1 (sangat tidak setuju) hingga 5 (sangat sesuai).

Definisi operasional pertama dari komitmen organsiasi adalah continuance comitment, yang berarti keinginan anggota untuk tetap menjadi anggota perusahaan karena membutuhkan keuntungan dari pekerjaannya, semakin tinggi continuance commitment yang diperoleh partisipan, maka partisipan semakin ingin untuk tetap menjadi anggota perusahaan. Dimensi ini memiliki empat indikator. Jumlah seluruhnya terdapat 12 buah peryantaan yaitu delapan butir positif dan empat butir negatif. Contoh penyataan dimensi continuance commitment adalah: "saat ini saya membutuhkan pekerjaan di perusahaan ini" dan "Banyak alternatif pekerjaan atau perusahaan lain apabila saya mau meninggalkan perusahaan saat ini". Nilai koefisien internal consistency reliability dimensi ini adalah 0.635. Butir 6 dan 7 memiliki nilai $r$ di bawah 0,2 sehingga ada pengurangan dua butir pada dimensi ini 
Definisi operasional kedua dari komitmen organisasi adalah affective commitment, yang berarti keinginan anggota untuk tetap menjadi anggota organisasi karena adanya ikatan secara emosional yang tercermin melalui keterlibatan dan perasaan senang serta menikmati aktivitasnya di dalam organisasi. Semakin tinggi affective commitment yang diperoleh partisipan maka semakin tinggi keinginan partisipan untuk menjadi anggota organisasi karena ikatan emonsional pada organisasi tersebut. Dimensi ini memiliki empat indikator. Jumlah seluruhnya ada 12 buah pernyataan yaitu delapan butir positif dan empat butir negatif, contoh penyataan dimenisi affective commitment adalah: "saya merasa perusahaan dan seluruh anggotanya adalah keluarga saya yang kedua" dan "tempat kerja saya saat ini kurang memberi kebanggaan bagi saya". Nilai koefisien internal consistency reliability dimensi ini adalah 0.676. Butir 3, 15 dan 24 memiliki nilai $r$ di bawah 0,2 sehingga ada pengurangan tiga butir pada dimensi ini

Definisi operasional ketiga dari komitmen organisasi adalah normative commitment, yang berarti keinginan anggota untuk tetap menjadi anggota organisasi karena ia merasa memiliki kewajiban untuk tetap berada di organisasi tersebut atau karena ia mereasa perusahaan telah banyak berbuat kebaikan sehingga ia merasa berhutang pada perusahaan. Semakin tinggi normative commitment yang diperoleh partisipan maka semakin tinggi keingginan untuk tetapmenjadi anggota organisasi karena merasa perusahaan telahbanyak berbuat kebaikan dan merasa berhutang pada perusahaan. Dimensi ini memiliki empat indikator. Jumlah seluruhnya ada 12 buah pernyataan yaitu delapan butir positif dan empat butir negatif, contoh penyataan dimenisi normative commitment adalah: "saya takut atasan saya akan berpikiran negati apabila saya berhenti bekerja saat ini" dan "saya tidak merasa wajib untuk terus menerus bekerja di perusahaan ini". Nilai koefisien internal consistency reliability dimensi ini adalah 0.728 tidak ada pengurangan jumlah butir pada dimensi ini.

\section{HASIL DAN PEMBAHASAN}

Penelitian yang bersifat deskriptif yang terdiri dari jenis kelamin, usia, pendidikan,Status pegawai, lama bekerja, level jabatan dan penghasilan. Dengan rentang penilaian $1-4$ peneliti membagi tiga kategori menjadi 1 - 2 kategori rendah, 2,01 - 3 kategori sedang, dan 3,01 - 4 kategori tinggi. Secara umum nilai rata-rata partisipan terhadap komitmen organisasi berada pada 2,618 (sedang). Partisipan yang tergolong komitmen organisasi rendah ada 14 orang (35\%) dan partisipan yang tergolong komitmen organisasi tinggi ada 26 orang (65\%).

\section{Jenis kelamin}

Dilihat berdasarkan jenis kelaminya mayoritas subyek dalam penelitian adalah wanita yaitu sebanyak 27 orang $(67.5 \%)$ sedangkan yang berjenis kelamin pria sebanyak 13 orang $(32.5 \%)$. Melihat gambaran komitmen berdasarkan jenis kelamin, partisipan pria memiliki komitmen organisasi lebih tinggi dibanding dengan wanita. Nilai rata-rata keseluruhan dimensi komitmen organisasi dari partisipan pria adalah 2,713 (sedang) sedangkan wanita adalah 2,572 (sedang).

Dilihat berdasarkan dimensi di setiap komitmen organisasi untuk partisipan pria dimensi affective comitment memiliki nilai rata-rata yang paling tiggi yaitu 3,098 (Tinggi) lalu continuance commitment memiliki rata-rata 2,560 (sedang), dan dimensi normative commitment memiliki nilai rata-rata 2,486 (sedang). Partisipan wanita juga menempatkan dimensi affective commitment yang merupakan nilai yang paling tinggi yaitu 2,8641 (sedang) diikuti dengan continuance commitmen dengan nilai rata-rata 2,485 (sedang), dan normative commitment 2,367 (sedang). 


\section{Usia}

Pembagian usia dibagi menjadi tiga golongan yaitu 18-25 tahun, 26 - 33 tahun dan diatas 33 tahun. Partisipan pada usia 18-25 tahun berjumlah 10 orang (25\%), pada usia 26-33 tahun berjumlah 40 orang (50\%), dan pada usia diatas 33 tahun berjumlah 10 orang (25\%). Partisipan pada usia diatas 33 tahun memiliki nilai rata-rata komitmen organisasi lebih tinggi dibandingkan dengan lainnya yaitu 2,791 (sedang) sedangkan pada usia18-25 tahun dengan nilai rata-rata 2,585 (sedang) dan pada usia 26-33 tahun dengan nilai rata-rata 2,548 (sedang).

Dilihat berdasarkan dimensi di setiap komitmen organisasi untuk partisipan usia 18-25 tahun menunjukkan nilai affectife commitment paling tinggi dibanding dengan dimensi lainnya dengan nilai rata-rata 2,991 (sedang) diikuti dengan dimensi continuance commitment dengan nilai ratarata 2,585 (sedang) dan dimensi normative commitment dengan nilai rata-rata 2,225 (sedang). Partisipan pada usia 26-33 tahun menunjukkan nilai affectife commitment paling tinggi dibanding dengan dimensi lainnya dengan nilai rata-rata 2,8085 (sedang) diikuti dengan dimensi continuance commitment dengan nilai rata-rata 2,518 (sedang) dan dimensi normative commitment dengan nilai rata-rata 2,3205 (sedang). Partisipan usia diatas 33 tahun menunjukkan nilai affectife commitment paling tinggi dibanding dengan dimensi lainnya dengan nilai rata-rata 3.153 (tinggi) diikuti dengan dimensi normative commitment dengan nilai rata-rata 2,758 (rendah) dan dimensi continuance commitment dengan nilai rata-rata 2,465 (sedang)

\section{Tingkat Pendidikan}

Dilihat berdasarkan tingkat pendidikan subyek mayoritas berpendidikan S1 yaitu 33 orang $(82.5 \%)$ sedangakn berpendidikan SMA 7 orang $(12.5 \%)$. Gambaran komitmen berdasarkan tingkat pendidikan partisipan yang berpendidikan S1 memiliki komitmen lebih tinggi dibandingkan dengan pendidikan SMA/SMK. Nilai rata-rata keseluruhan dimensi organisasi dari partisipan berpendidikan S1 adalah 2.623 (sedang) sedangkan SMA/SMK adalah 2,592 (sedang)

Partisipan dengan pendidikan S1 memiliki nilai affective commitment paling tinggi dibanding dengan dimensi lainnya yaitu dengan nilai rata-rata 2,956 (sedang) sedangkan dimensi continuance commitment memiliki nilai rata-rata 2,487 (sedang) serta dimensi normative commitment memiliki nilai rata-rata 2,426 (sedang). Partisipan dengan pendidikan SMA/SMK juga memiliki nilai rata-rata yang tinggi pada dimensi affective commitment yaitu dengan nilai rata-rata 2,861 (sedang) diikuti dengan continuance commitment dengan nilai rata-rata 2,612 (sedang) dan dimensi normative commitment dengan nilai rata-rata 2,31 (sedang).

\section{Status Pegawai}

Dilihat berdasarkan status pegawai subyek mayoritas adalah karyawan tetap dengan 34 orang $(85 \%)$ dan karyawan kontrak dengan 6 orang $(15 \%)$. Gambaran komitmen berdasarkan status pegawai adalah karyawan kontrak memiliki rata-rata komitmen organisasi yang lebih tinggi dibandingkan dengan karyawan tetap yaitu 2.68 (sedang) sedangkan karyawan tetap nilai ratarata 2.607 (sedang).

Partisipan dengan status pegawai kontrak memiliki nilai affective commitment paling tinggi dibanding dengan dimensi lainnya yaitu dengan nilai 3,066 (tinggi) diikuti dengan normative commitment dengan nilai rata-rata 2,555 (sedang) dan comtinuance commitment dengan nilai 2,425 (sedang). Partisipan dengan status pegawai tetap memiliki nilai rata-rata dimensi affective commitment paling tinggi dibanding dengan dimensi lain yaitu 2,917 (sedang) diikuti dengan nilai dimensi continuance commitemnt yaitu 2,524 (sedang) dan nilai normative commitment dengan nilai rata-rata 2,379 (sedang). 


\section{Lama Bekerja}

Dilihat berdasarkan lama bekerja membaginya menjadi tiga kelompok yaitu masa kerja dengan 0 - 3 tahun dengan 26 orang (65\%), 3- 6 tahun dengan 8 orang (20\%), dan >6 tahun dengan 6 orang $(15 \%)$.Gambaran komitmen berdasarkan lama bekerja adalah karyawan dengan lama bekerja $>6$ tahun memiliki nilai rata-rata komitmen organisasi lebih tinggi yaitu 2,696 (sedang) sedangkan partisipan dengan lama bekerja 0-3 tahun memiliki nilai rata-rat 2,624 (sedang) dan partisipan dengan lama bekerja 3-6 tahun memiliki nilai rata-rata 2,493 (sedang).

Partisipan dengan lama bekerja 0 - 3 tahun menunjukkan dimensi affective commitment memiliki nilai rata-rata paling tinggi yaitu dengan 2,948 (sedang) diikuti dengan dimensi continuance commitment memiliki nilai rata-rata 2,498 (sedang) dan dimensi normative commitment dengan nilai rata-rata 2,426 (sedang). Partisipan dengan lama bekerja 3 - 6 tahun menunjukkan dimensi affective commitment memiliki nilai rata-rata paling tinggi yaitu dengan 2,782 (sedang) diikuti dengan dimensi continuance commitment memiliki nilai rata-rata 2,522 (sedang) dan dimensi normative commitment dengan nilai rata-rata 2,1775 (sedang). Partisipan dengan lama bekerja $>6$ ahun menunjukkan dimensi affective commitment memiliki nilai rata-rata paling tinggi yaitu dengan 2,961 (sedang) diikuti dengan dimensi normative commitment memiliki nilai rata-rata 2,708 (sedang) dan dimensi continuance commitment dengan nilai rata-rata 2,425 (sedang).

\section{Level Jabatan}

Perusahaan PT. XYZ membagi level jabatan karyawan 6 level jabatan. Level 1 setingkat pelaksana (OB,Driver,Messenger), Level 2 Staf, Level 3 Supervisor, Level 4 Asistant Manager,Level 5 Manager dan level 6 Direktur. Dilihat dari level jabatan subyek mayoritas adalah staf dengan 20 orang (50\%), Manager dengan 8 orang (20\%), supervisor dengan 7 orang (17.5\%), Asistant Manager 2 orang (5\%) dan pelaksana 3 orang(7.5\%). Data pada perusahaan PT. XYZ menggambarkan bahwa komitmen organisasi yang tinggi ada pada level manager dengan nilai rata-rata dimensi 2,73(sedang). Supervisor dengan nilai rata-rata 2,63 (sedang), Staf dengan nilai rata-rata 2,622 (sedang), pelaksana dengan nilai rata-rata 2,63 (sedang), dan asistant manager dengan nilai rata-rata 2,43 (sedang).

Partisipan dengan level 1 menunjukkan dimensi continuance commitment memiliki nilai ratarata paling tinggi yaitu dengan 2,682 (sedang) diikuti dengan dimensi affective commitment dengan nilai rata-rata 2,597 (sedang) dan dimensi normative commitment dengan nilai rata-rata 2,312 (sedang). Partisipan pada level 2 menunjukkan dimensi continuance commitment memmiliki nilai rata-rata paling tinggi yaitu dengan 2,561 (sedang) diikuti dengan normative commitment dengan nilai rata-rata 2,345 (sedang) dan affective commitment 2,296 (sedang). Partisipan dengan level 3 menunjukan dimensi affective commitment dengan nilai rata-rata 2,984 (sedang) diikuti dengan continuance commitment dengan nilai rata-rata 2,535 (sedang) dan normative commitment dengan nilai rata-rata 2,38 (sedang).

Partisipan dengan level 4 menunjukkan dimensi affective commitment memilki nilai rata-rata paling tinggi yaitu 2,88 (sedang) diikuti dengan continuance commitment dengan nilai rata-rata 2,32 (sedang) dan dimensi normative commitment dengan nilai rata-rata 2,25 (sedang). Partisipan level 5 menunjukkan dimensi affective commitment memiliki nilai rata-rata paling tinggi yaitu 3,144 (tinggi) diikuti dengan normative commitment dengan nilai rata-rata 2,698 (sedang) dan continuance commitment dengan nilai rata-rata 2,387 (sedang). 


\section{Penghasilan}

PT. XYZ membagi penghasilan dalam 4 kategori yaitu untuk kategori satu Rp 2.000.000 - Rp 4.999.999; kategori dua Rp 5.000.000 - Rp 9.999.999; kategori tiga Rp 10.000.000 - Rp 19.999.999; dan diatas Rp 20.000.000. Dilihat berdasarkan penghasilan subyek mayoritas ada di kategori pertama dengan 17 orang (42.5\%), kategori kedua 16 orang (40\%), dan kategori ketiga 7 orang (17.5\%). Data berdasarkan penghasilan menggambarkan penghasilan kategori ketiga memiliki rata-rata komitmen organisasi yang tinggi yaitu 2,694 (sedang) sedangkan kategori satu dengan nilai rata-rata 2,61 (sedang) dan kategori dua 2,593 (sedang).

Partisipan dengan penghasilan pada kategori satu menunjukkan dimensi affective commitment memiliki nilai rata-rata paling tinggi yaitu 2,848 (sedang) disusul dengan continuance commitment dengan nilai rata-rata 2,642 (sedang) dan dimensi normative commitment dengan nilai rata-rata 2,337 (sedang). Partispan dengan penghasilan kategori dua menunjukkan dimensi affective commitment memiliki nilai rata-rata paling tinggi dengan nilai rata-rata 2,963 (sedang) diikuti dengan dimensi continuance commitment dengan nilai rata-rata 2,443 (sedang) dan dimensi normative commitment dengan nilai rata-rata 2,375 (sedang). Partisipan dengan kategori penghasilan ketiga menunjukan dimensi affective commitment memiliki nilai rata-rata paling tinggi dibandingkan dengan dimensi lainnya yaitu dengan nilai rata-rata 3,11 (tinggi) diikuti dengan dimensi normative commitment dengan nilai 2,642 (sedang) dan dimensi continuance commitment dengan nilai rata-rata 2,337 (sedang).

\section{KESIMPULAN DAN SARAN}

Hasil analisi deskriptif menyimpulkan diperoleh bahwa secara umum karyawan PT. XYZ memiliki komitmen yang tergolong tinggi hasil ini menunjukkan bahwa secara umum karyawan memiliki keterikatan emosional yang kuat terhadap organisasinya. Ikatan emosional terhadap organisasi ditunjukkan dengan kepercayaan terhadap nilai-nilai organisasi, kesediaan berusaha sebaik mungkin demi kepentingan organisasi dan loyalitas terhadap organisasi.

Komitmen organisasi pada PT. XYZ dominan dengan dimensi affective commitment diikuti dengan continuance commitment dan normative commitment. Melihat hasil tersebut menunjukkan keterikatan emosional yang tinggi antar karyawan yang memiliki perasaan senang jika berada di dalam organisasi atau perusahaan sehingga komitmen rata-rata karyawan tinggi dikarenakan ada ikatan emosional yang kuat pada perusahaan.

Gambaran komitmen organisasi karyawan pada PT. XYZ menunjukan pria lebih memiliki komitmen lebih tinggi dibandingkan dengan wanita, semakin tinggi usia seseorang juga menunjukkan semakin tinggi komitmen organisasinya, serta semakin lama masa kerjanya di perusahaan menunjukkan semakin tinggi komitmnenya, semakin tinggi jabatan makan semakin tinggi komitmennya, semakin tinggi penghasilanya maka semakin tinggi komitmennya, dan semakin tinggi tingkat pendidikan semakin tinggi pula komitmen organisasinya. Hanya saja untuk karyawan yang berstatus kontrak memiliki komitmen yang lebih tinggi dibandingkan dengan karyawan yangberstatus tetap.

Ucapan Terima Kasih (Acknowledgement)

Terima kasih kepada partisipan dan perusahaan PT XYZ yang telah memberikan kesempatan kepada penulis untuk penelitian. Serta phak Universitas Tarumanagara. 


\section{REFERENSI}

Abdulah, D. (2017). Pengaruh komitmen organisasional dan lingkungan psikologis terhadap produktivitas kerja karyawan bank BJB babang majalengka. Jurnal Ilmiah Manajemen \& Akuransi, 4(1), pp. 1-8

AlBattat, A. R., Som, A. P. M., \& Helahat, A. S. (2013). Overcoming staff turnover in the hospitality industry using mobley's model. Journal of Learning \& Developmment, 3(6), pp. 64-71

Allen, N. J., \& Meyer, J. P. (1990). The measurment and tecendents of affective, continuance, and normative commitment to the organization. Journal of Occupational Psyhology. 63, $1-18$.

Falkenburg, K. \& Schyns, B. (2007). Work satisfaction, organizational commitment and withdrawal behaviors. Management Research News, 30(10), 708-723

Fry,L.W., Vitucci., \& Ceddilo. (2005). Spritual leadership and army tranformation theory, measurement, and estabhlising a baseline. The Teadershio Quarterly, 16, 835-862.

Hernawaty. (2017). Pengaruh komitmen organisasi dan budaya terhadap produktivitas karyawan pada pt home center Medan. Jurnal SMART, 1(1), pp. 1 -10

Satwari, T., Musadieq, M. A. A \& frianty, T. W. (2016). Pengaruh komitmen organisasional terhadap turnover intention (survei pada karyawan hotel swiss-belinn Malang). Jurnal Administrasi Binis, 40(2), pp. 177-186

Sersic, D. M. (1999). An empirical test of meyer and allen's three-component model of organizational commitment in a Croatian context. Journal of Review Psychology, 6(1,2), pp. 17-24

Tamonsang, M., \& Dihardjo, D. (2017). Pengaruh kepuasan kerja dan komitmen organisasi dalam pengaruhnya terhadap kinerja karyawan dengan keaktifan gugus kendali mutu sebagai variabel moderasi di kantor disnakertrans provinsi Jawa Timur. Seminar Nasional Sitem Informasi, pp. 408-416

Wahyudi, N. K. S., \& Sudibya, I. G. A. (2016). Pengaruh kepuasan kerja dan komitmen organisasional pada kinerja karyawan di natya hotel, Kuta Bali. E-Jurnal Manajemen Unud 5(2), pp. 820-897 